\title{
Use of vitrified urban incinerator waste as raw material for production of sintered glass-ceramics
}

\section{Romero, J.Ma. Rincón}

Instituto E. Torroja de Ciencias de la Construcción, Serrano Galvache s/n, 28033 Madrid, Spain

\section{R.D. Rawlings}

Imperial College of Science, Department of Materials, Prince Consort Road, London SW7 2BP, United Kingdom

\section{A.R. Boccaccini}

Institut für Werkstofftechnik, Technische Universität Ilmenau, PF 100565, D-98684 Ilmenau, Germany

\begin{abstract}
The crystallisation behaviour of vitrified industrial waste (fly ash from domiciliary solid waste incineration) was examined by differential thermal analysis, X-ray diffractometry and scanning electron microscopy. It was demonstrated that powder processing route was required to transform the vitrified industrial waste into glass-ceramics products. Time-Temperature-Transformation (TTT) diagrams were drawn for the two main crystalline phases, diopside and wollastonite. The wollastonite existed in both monoclinic and triclinic forms and an iron-rich phase was also observed at the boundaries between glass particles. The morphology of the crystalline phases and the development of microstructure were observed as a function of heat treatment time and temperature. The optimum heat treatment was $900^{\circ} \mathrm{C}$ for $40-50$ minutes.
\end{abstract}

KEYWORDS: A. glasses, A. ceramics, C. X-ray diffraction, C. electron microscopy, D. microstructure

\section{INTRODUCTION}

Industrial development over the last decades has generated large amounts of toxic and hazardous inorganic waste, for example fly-ash, slags and muds which contain appreciable amounts of $\mathrm{Pb}, \mathrm{Cr}, \mathrm{Cu}, \mathrm{Zn}, \mathrm{Cd}$ and $\mathrm{Hg}$. Most is buried in landfills, which is costly and environmentally unsatisfactory. Therefore, it essential to seek new options to recycle or reuse the inorganic residues.

In developed countries each inhabitant is estimated to produce $1 \mathrm{~kg} /$ day of domiciliary solid waste (DSW); the total for the European Union (EU) is about $13.9 \times 10^{6}$ ton/year. Recycling, which involves selection and classification of the waste is suitable for only $47 \%$ of DSW and hence, recycling alone cannot solve the disposal problem. The complementary and growing option in Europe, for disposal of the non-recyclable fraction (53\%), is incineration with energy recovery. Unfortunately, incineration leaves large amounts of solids residues, such as fly ashes and slags, which form 10-25 wt\%)of the DSW incinerated. The total production for the EU is about $1.12 \times 10^{6}$ ton/year of 
residues, most of which is buried in landfills. The increasing tendency for waste incineration, together with the disadvantages of landfill disposal, makes it essential to search for new options for reuse of the solid residues from waste incineration.

Recycling is well-established for wastes such as exemplified by glass and aluminium, but is not always feasible and it is necessary to develop alternative processes for reuse. Recent reuses proposed for fly-ash, slags and muds include fabrication of building materials [1, 2], catalysts and pigments [3], refractories [4], puzzolanic material [5], glasses and glass-ceramics [6-9].

Glass-ceramics prepared by controlled devitrification of glasses were developed in the 1950s $[10,11]$ and find a wide variety of applications such as microelectronic substrates and packaging [12, 13], optically transparent components [14-16], biomedical implants $[17,18]$, catalytic supports, membranes and sensors [19] as well as for the matrix of composite materials [20, 21].

The earliest glass-ceramics were produced by a conventional glass route and subsequently crystallised, usually by heat treatment in two stages give nucleation followed crystal growth [22]. More recently, a powder-processing route, similar to that used for "conventional” ceramics, has been developed in which the glass is reduced to a fine powder, shaped and crystallised. During heating the glass particles densify by viscous flow and then nucleate and crystallise from the original glass particle boundaries [23].

For glass-ceramic production via conventional glass processing nuclei must readily form throughout the bulk of the parent glass; surface nucleation is to be avoided as it is usually detrimental to mechanical performance. In contrast, glasses showing a strong tendency for surface crystallisation may be successfully converted into glass-ceramics by the powder processing route [24]. Consequently, microstructure of a glass-ceramic produced by the two routes is different.

It is essential that the microstructure, and hence properties, of a glass-ceramic be optimised. This is achieved by control of the thermal history of the parent glass, especially the heat treatment time and temperature. In this context, Time-TemperatureTransformation (TTT) diagrams are extremely useful; they may be used as guides for heat treatment scheduling in the processing of glasses [25] and glass-ceramics [26], to assess glass-forming ability [27], to predict critical cooling rates [28] and as an aid to the analysis of phenomena such as phase separation and the precipitation of stable and metastable crystals [27].

It has previously been shown that glasses, and conventionally processed and sintered glass-ceramics, can be produced by vitrification of DSW incinerator fly ashes [29-33]. However, to our knowledge, TTT diagrams for these materials are not available and form the basis of the present study together with microstructural and mechanical property measurements of the resulting glass-ceramics.

\section{EXPERIMENTAL PROCEDURE}

Chemical analysis of the incinerator fly ash was determined using an inductively coupled plasma method (ICP-Atomic Emission Spectroscopy). A $60 \mathrm{~g}$ batch of fly ash 
was placed in Pt crucible in an electric furnace and heated in air at $10^{\circ} \mathrm{C} \mathrm{min}^{-1}$ to $1500^{\circ} \mathrm{C}$, held for $30 \mathrm{~min}$ at $1500^{\circ} \mathrm{C}$ and the resulting melt poured onto a cold metal plate and allowed to cool to room temperature. The resulting glass was crushed and sieved to a particle size $<75 \mu \mathrm{m}$. Cylindrical compacts $(10 \mathrm{~mm}$ x $15 \mathrm{~mm})$ were fabricated by uniaxial cold-pressing the powder at $250 \mathrm{MPa}$ without using binder.

Differential thermal analysis (DTA) was employed (Netzsch thermal analyser, STA 409 Series) to determine the crystallisation behaviour and the glass transition temperature $\left(\mathrm{T}_{\mathrm{g}}\right)$ of the parent glass. Pt crucibles were used with calcined alumina as reference in flowing air at $100 \mathrm{~cm}^{3} \mathrm{~min}^{-1}$ and a heating rate of $25^{\circ} \mathrm{C} \mathrm{min}$. DTA was performed on both bulk monolithic $\left(4 \times 2 \times 2 \mathrm{~mm}^{3}\right)$ and powder samples. The DTA curves were normalised with respect to the sample weight.

Glass-ceramics were prepared by sintering the cylindrical glass compacts in air. The compacts were heated at a rate of $10^{\circ} \mathrm{C} \mathrm{min}^{-1}$ to a temperature in the range 800 to $925^{\circ} \mathrm{C}$, held for times in the range 4-120 min and then samples cooled in the furnace.

After heat treatment, the samples were ground and sieved to a particle size $<70 \mu \mathrm{m}$ and X-ray diffraction (XRD) data were obtained (Philips analytical diffractometer, PW 1710 Series, using $\mathrm{CuK}_{\alpha}$ radiation). The relative crystallisation range was determined by drawing the TTT curve from the time and temperature when crystallisation became noticeable by XRD. The heat-treated glass was considered to be "amorphous" when no XRD peaks corresponding to crystalline phases were observed, "partial crystallisation" when small peaks appeared and "total crystallisation" when these peaks were intense and there was no evidence at low $2 \theta$ of a glassy phase. The boundary between "amorphous" and "partially crystallised" states represent the onset of crystallisation.

Scanning electron microscopy (SEM) was used to examine the crystalline morphology of the sintered glass-ceramics. Samples were embedded in epoxy and surfaces ground (120, 320, 600 grit abrasive paper) and polished with diamond spray ( $6 \mu \mathrm{m}, 3 \mu \mathrm{m}$ and 1 $\mu \mathrm{m})$. Energy dispersive X-ray (EDX) analysis was used for elemental analysis.

\section{RESULTS AND DISCUSSION}

Table 1 shows the composition of the fly ash. The major components were $\mathrm{CaO}$ and $\mathrm{SiO}_{2}$ although the $\mathrm{SiO}_{2}$ content was considerably less than reported previously for urban incinerator fly ashes [32]. There was a significant loss on ignition (LOI), which was probably due to volatiles associated with decomposition of the different calcium compounds and the presence of residual carbon. The sum of oxides plus LOI was near to $80 \%$; the remaining $20 \%$ corresponds to elements such as $\mathrm{Cl}$ and $\mathrm{S}$ that cannot be determined by ICP.

In spite of the low $\mathrm{SiO}_{2}$ content, the melting and casting techniques used produced a glass. DTA results are shown in Figure 1; both bulk and powder samples exhibit a glass transition at around $740^{\circ} \mathrm{C}$. In contrast to previous studies [30, 32], the bulk sample does not exhibit crystallisation peaks. This is attributed to the lower amount of nucleating agents, such as $\mathrm{Fe}_{2} \mathrm{O}_{3}, \mathrm{P}_{2} \mathrm{O}_{5}$ and $\mathrm{TiO}_{2}$, in the present glass. However, the powder sample has two exothermic peaks at $980^{\circ} \mathrm{C}$ and $1025^{\circ} \mathrm{C}$ followed by an endothermic at $1100^{\circ} \mathrm{C}$, indicating either re-solution of a crystalline phase or the formation of a liquid phase. The crystallisation of the powder sample is attributed to its large surface area facilitating 
surface crystallisation. These results indicate that this particular incinerator fly-ash glass could be converted into a glass-ceramic using the processing route. Similar crystallisation behaviour was observed in glasses from the systems $\mathrm{MgO}-\mathrm{Al}_{2} \mathrm{O}_{3}-\mathrm{SiO}_{2}$ $[24,34]$ and $\mathrm{Na}_{2} \mathrm{O}-\mathrm{SiO}_{2}[35]$.

Table 1. Chemical analysis (wt\% ) of the investigated incinerator fly ash

\begin{tabular}{lc}
\hline OXIDE & $\begin{array}{r}\text { PERCENTAGE } \\
\text { (wt\%) }\end{array}$ \\
\hline $\mathrm{SiO}_{2}$ & 11.47 \\
$\mathrm{Al}_{2} \mathrm{O}_{3}$ & 5.75 \\
$\mathrm{Fe}_{2} \mathrm{O}_{3}$ & 1.29 \\
$\mathrm{MgO}$ & 3.02 \\
$\mathrm{CaO}$ & 29.34 \\
$\mathrm{Na}_{2} \mathrm{O}$ & 8.70 \\
$\mathrm{~K}_{2} \mathrm{O}$ & 7.02 \\
$\mathrm{P}_{2} \mathrm{O}_{5}$ & 1.69 \\
$\mathrm{TiO}_{2}$ & 0.85 \\
$\mathrm{MnO}$ & 0.18 \\
$\mathbf{L O I}$ & 9,2 \\
& \\
\hline TOTAL & 78.51 \\
\hline
\end{tabular}

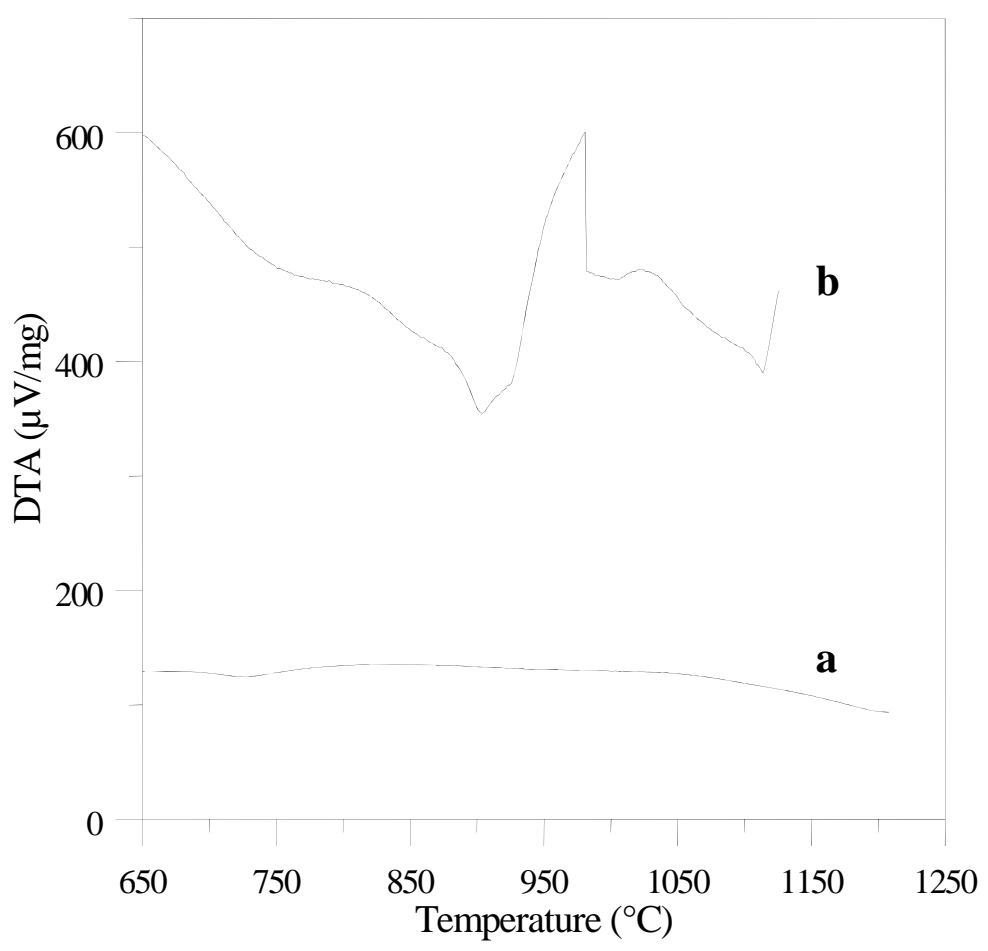

Figure 1. DTA curves for bulk (a) and powder (b) vitrified incinerator fly-ash glass. 
Figure 2 presents the TTT diagram for the crystallisation of the incinerator fly-ash glass. The C-shaped curves, which are characteristic of nucleation and growth processes, give the combinations of time and temperature needed for the onset of crystallisation. Thus, at or above $775^{\circ} \mathrm{C}$ led to a least partial devitrification of the glass compacts. At $775^{\circ} \mathrm{C}$ and $800^{\circ} \mathrm{C}$, crystallisation still has not reached completion after 60 minutes. The glass compacts are fully devitrified at or above $850^{\circ} \mathrm{C}$ within the times employed. The fastest rate of crystallisation is at $900^{\circ} \mathrm{C}$ where the onset time was only 3 minutes.

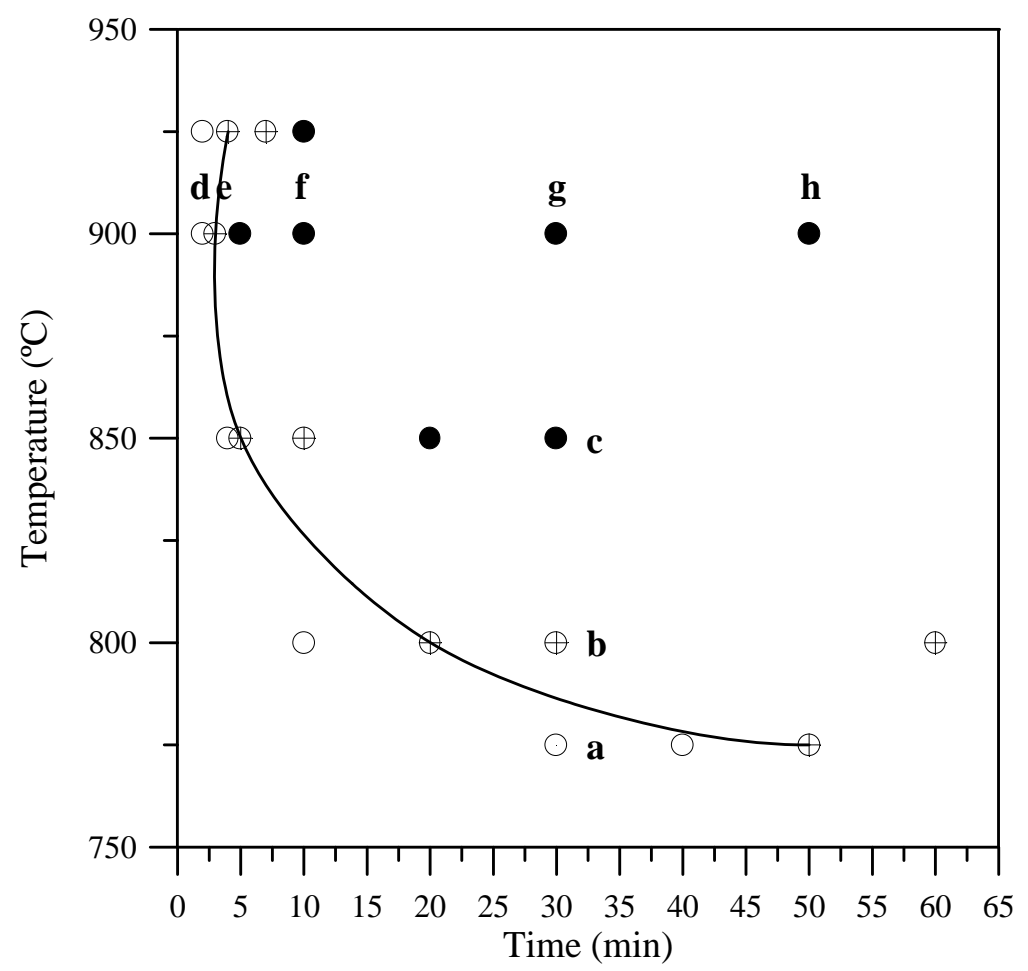

Figure 2. TTT diagram for incinerator fly-ash glass ( $\bigcirc$ amorphous; $\oplus$ partial crystallisation; $\bigcirc$ total crystallisation

The crystalline phases identified by XRD are diopside $\left(\mathrm{CaMg}\left(\mathrm{SiO}_{3}\right)_{2}\right)$ and both monoclinic and triclinic wollastonite $\left(\mathrm{CaSiO}_{3}\right)$. The TTT diagram for each is given in Figure 3. The two wollastonite phases crystallise in the same temperature-time interval and hence, their formation is represented by a single curve. Diopside starts to crystallise at lower temperatures and shorter times than wollastonite. Thus, the lower temperature DTA exotherm is due to the crystallisation of diopside and the higher temperature peak is associated with wollastonite. The shape of the TTT curves at $850^{\circ} \mathrm{C}$ and below indicates that the activation energy for crystallisation of wollastonite is much higher than for diopside with approximate values of $500 \mathrm{~kJ} \mathrm{~mol}^{-1}$ and $270 \mathrm{~kJ} \mathrm{~mol}^{-1}$ respectively. Furthermore, Figure 3 shows that with a suitable thermal treatment schedule, it is possible to prepare glass-ceramics comprising of one (diopside) or two (diopside and wollastonite) crystalline phases. However, the relative location of the TTT curves indicates that it is impossible to prepare glass-ceramics with wollastonite as the only crystalline phase. 


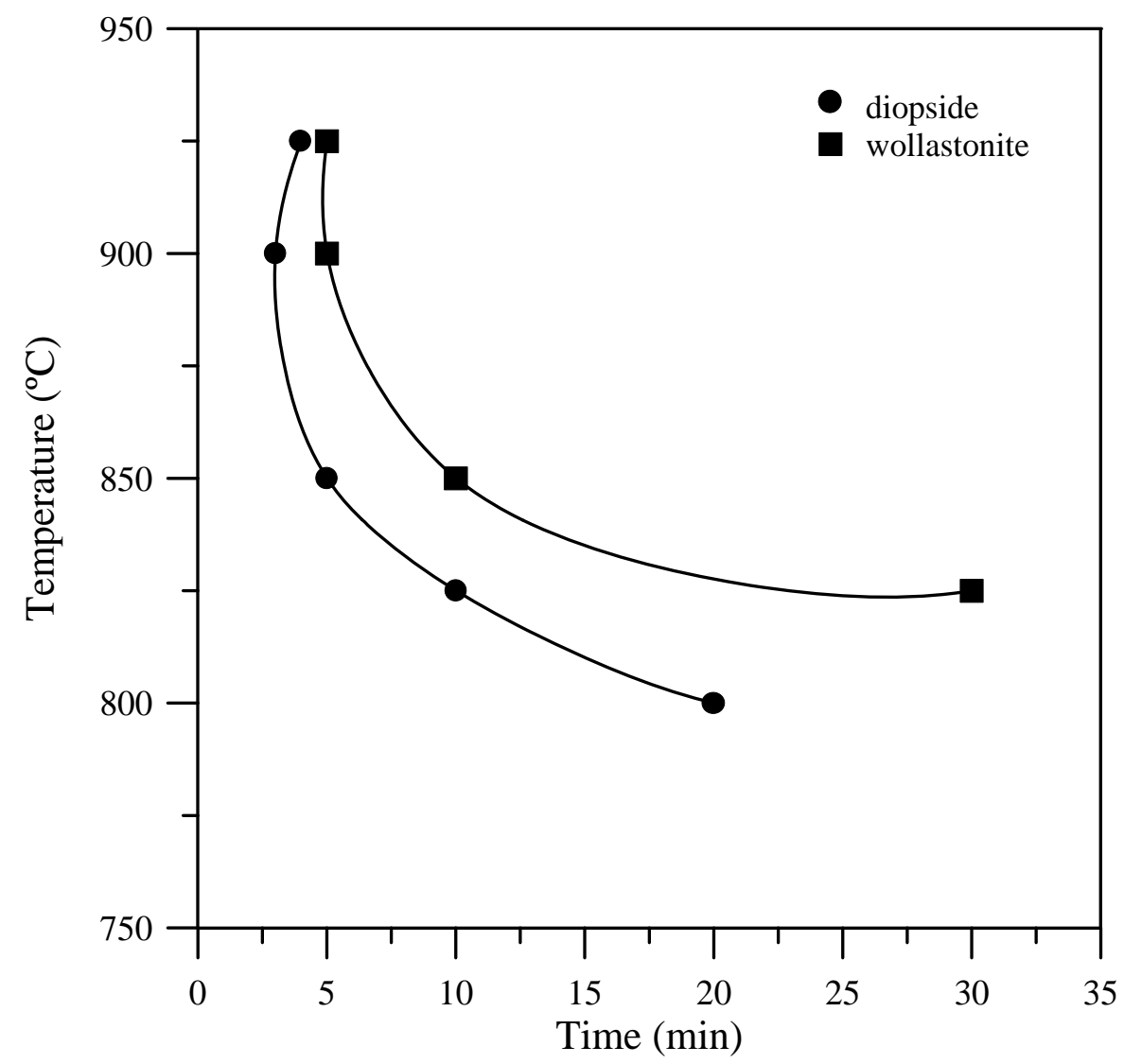

Figure 3. TTT diagram for diopside and wollastonite phases devitrified from incinerator fly-ash glass compacts.

The relative proportions of the various phases were estimated by XRD from the ratio $\mathrm{I}_{\text {relative }}=\mathrm{I}_{\mathrm{n}} / \mathrm{I}_{\text {total }}$. The peaks used for $\mathrm{I}_{\mathrm{n}}$ were $3.00-3.01 \AA$ (diopside), $3.07-3.08 \AA$ (triclinic wollastonite) and $2.17-2.18 \AA$ (monoclinic wollastonite).

Plots of $\mathrm{I}_{\text {relative }}$ versus crystallisation temperature and time are given in Figures 4 and 5, respectively. Only diopside is present at $775^{\circ} \mathrm{C}$ but monoclinic and triclinic wollastonite appear by $825^{\circ} \mathrm{C}$. The relative proportion of the three phases initially increases with temperature and time. Figure 4 is consistent with Figure 2 in that it demonstrates maximum crystallinity at $900^{\circ} \mathrm{C}$ and hence, this is the optimum temperature for glass devitrification. Both Figures 2 and 4 show crystallisation to be slower at $925^{\circ} \mathrm{C}$ than at $900^{\circ} \mathrm{C}$. From Figure 5, it may be concluded that 20 minutes is sufficient for almost complete crystallisation of triclinic wollastonite. In contrast, 40 and 50 minutes are required for the maximum proportions of monoclinic wollastonite and diopside respectively but at longer times there is partial solution of these phases. The shape of the curves in Fig. 5 suggests that devitrification occurs essentially by a steady state heterogeneous nucleation mechanism without a significant induction period [36]. 


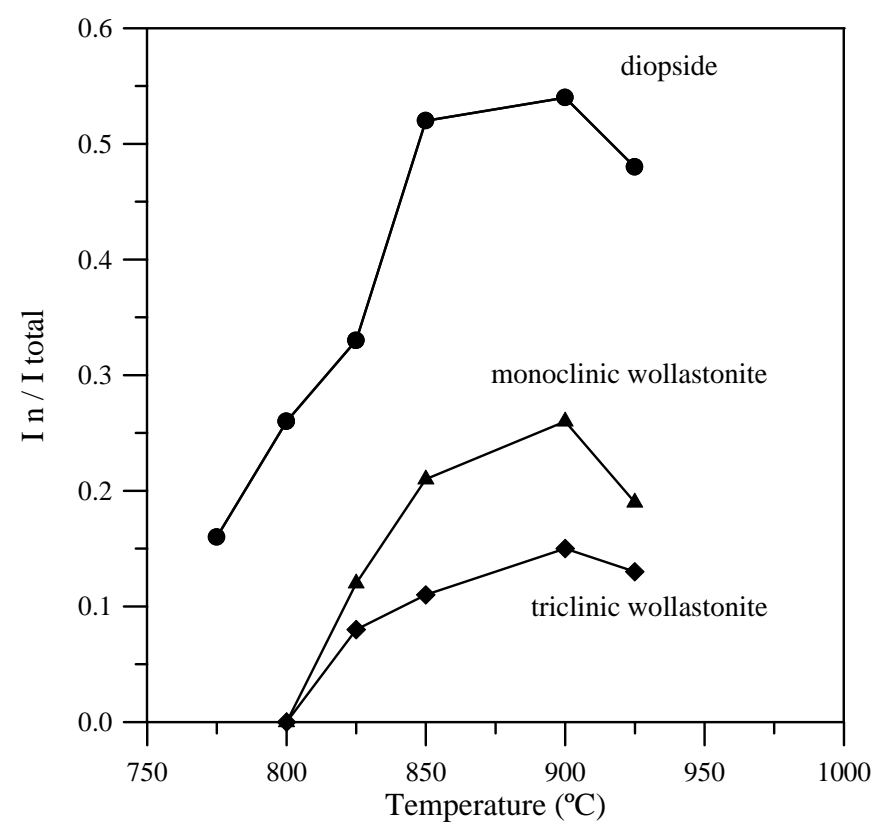

Figure 4. Plot of $\mathrm{I}_{\mathrm{n}} / \mathrm{I}_{\text {total }}$ versus crystallisation temperature for incinerator fly-ash glass (heat treatment time is $30 \mathrm{~min}$.).

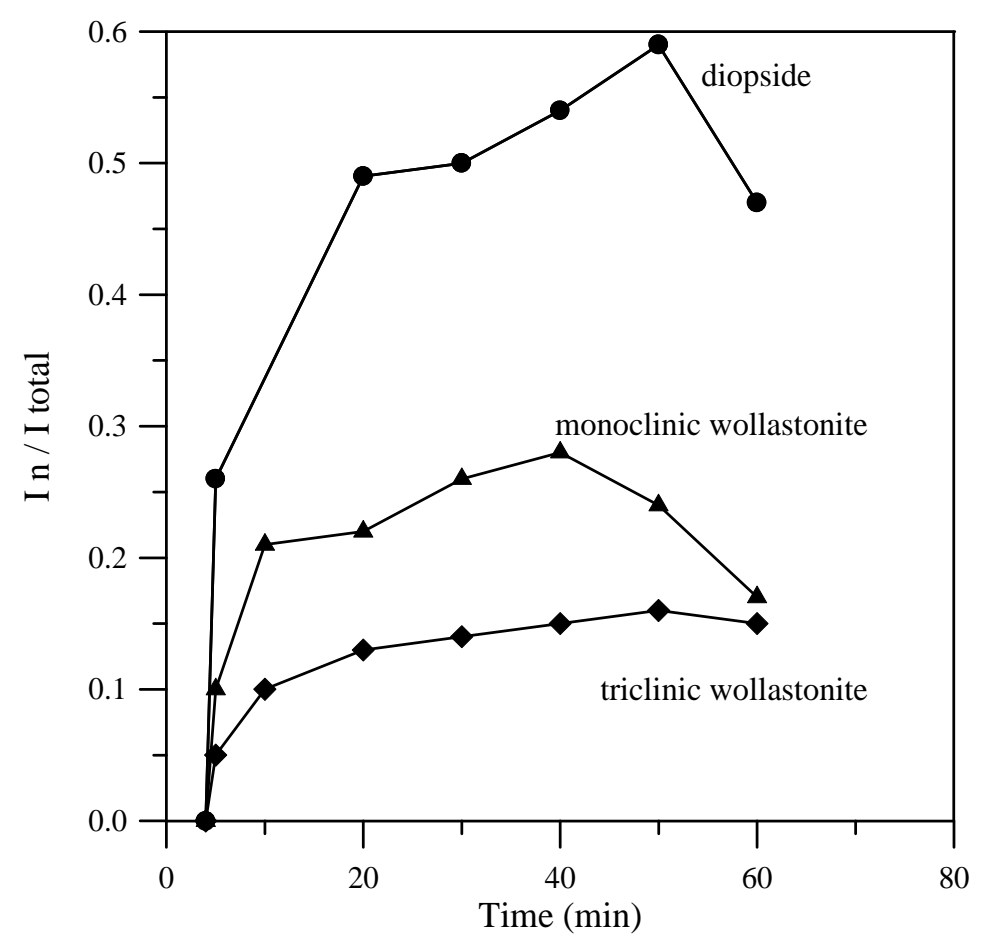

Figure 5. Plot of $I_{n} / I_{\text {total }}$ versus crystallisation time at $900^{\circ} \mathrm{C}$ for incinerator fly-ash glass. 
Figures 6-8 provide SEM images, EDX analyses and XRD patterns of the heat-treated samples for the time-temperature conditions indicated by points (a)-(h) in Figure 2. In Figure 6, samples (a) to (c) were heat treated at various temperatures for 30 minutes.

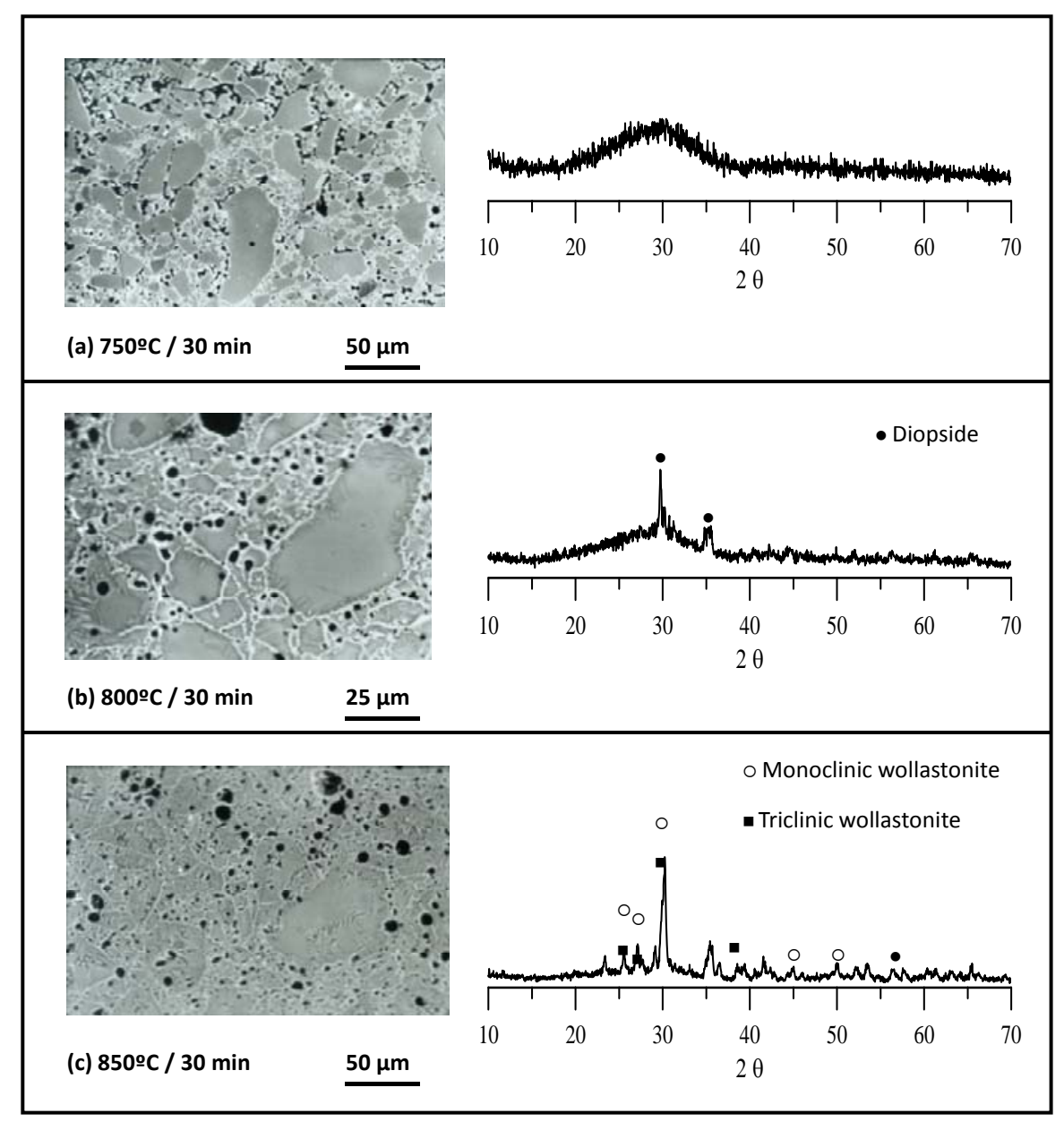

Figure 6. SEM images and XRD patterns for samples heat treated for 30 minutes at various temperatures as indicated by the points labelled (a) to (c) in Figure 2.

The XRD pattern of (a) is characteristic of a glass and the accompanying SEM photograph reveals a microstructure typical of an intermediate state of densification an almost continuous channel of pores at particle boundaries [37]. This sample, and all others exhibited anomalous white contrast at the particle boundaries due to higher secondary and backscattered electron emission as a result of an increase of Fe content at the boundaries. Segregation of solutes from the interior of a grain to the vicinity of a grain boundary is commonly observed in sintered materials [38]. Also, it is wellestablished that Fe ions have strong tendency to diffuse to the surface during bulk glass crystallisation giving rise to an iridescent layer [39]. In the present case, each particle acts as an individual small bulk glass sample as far as diffusion and segregation of Fe is concerned thus causing the observed particle boundary contrast. For sample (b), which is partially crystallised, the formation of diopside is noticeable in the XRD pattern and the morphology corresponds to a final stage of sintering with closed and spherical pores located in both particle boundaries (intergranular) and within the particles (intragranular). When the temperature is increased to $850^{\circ} \mathrm{C}$ the sample is fully 
crystallised and diopside, monoclinic and triclinic wollastonite are observed throughout the entire sample, Figure 6(c).

Figures 7 and 8 illustrate the effects of isothermal annealing at $900^{\circ} \mathrm{C}$ for various times (3-50 min). At $900^{\circ} \mathrm{C}$ for $3 \mathrm{~min}$ an amorphous sintered material is obtained, Figure 7(d). After $4 \mathrm{~min}$, the effect of iron segregation is more marked with heterogeneous crystallisation of a high density of small white crystals $(<1 \mu \mathrm{m}$ size $)$ at particle boundaries [40]. Further evidence of the effectiveness of particle boundary nucleation is the presence of diopside needle-like crystals, growing perpendicular to the boundary, which are heavily enriched in $\mathrm{Fe}_{2} \mathrm{O}_{3}$ compared with the amorphous sample (Fig.7(d)), consistent with the segregation of iron to the boundaries. EDX analysis also shows a high $\mathrm{SiO}_{2}, \mathrm{CaO}$ and $\mathrm{Al}_{2} \mathrm{O}_{3}$ contents in the boundary regions; this is a consequence of the small size of crystals at the particle boundaries, $<1 \mu \mathrm{m}$, which is comparable to the analytical resolution of the SEM/EDX system. Thus, EDX analyses on particle boundary crystals are influenced by the glassy phase and diopside crystals surrounding the boundary. The $\mathrm{SiO}_{2} / \mathrm{MgO}$ ratio of the diopside phase is about 6 , which is double in $\mathrm{CaMgSi}_{2} \mathrm{O}_{6}$. This, together with the high $\mathrm{Fe}_{2} \mathrm{O}_{3}$ content, is attributed to the wide variety of ionic substitutions that occur in the members of the pyroxene group with, for example, complete solid solution between diopside $\left(\mathrm{CaMgSi}_{2} \mathrm{O}_{6}\right)$, hedenbergite $\left(\mathrm{CaFeSi}_{2} \mathrm{O}_{6}\right)$, augite and ferroaugite $(\mathrm{CaMgFe}) \mathrm{SiO}_{3}$ [41]. Increasing the heat-treatment time to 5 minutes enables further development of the diopside phase into an interconnected network of feather-like crystals (Figure 7(f)).

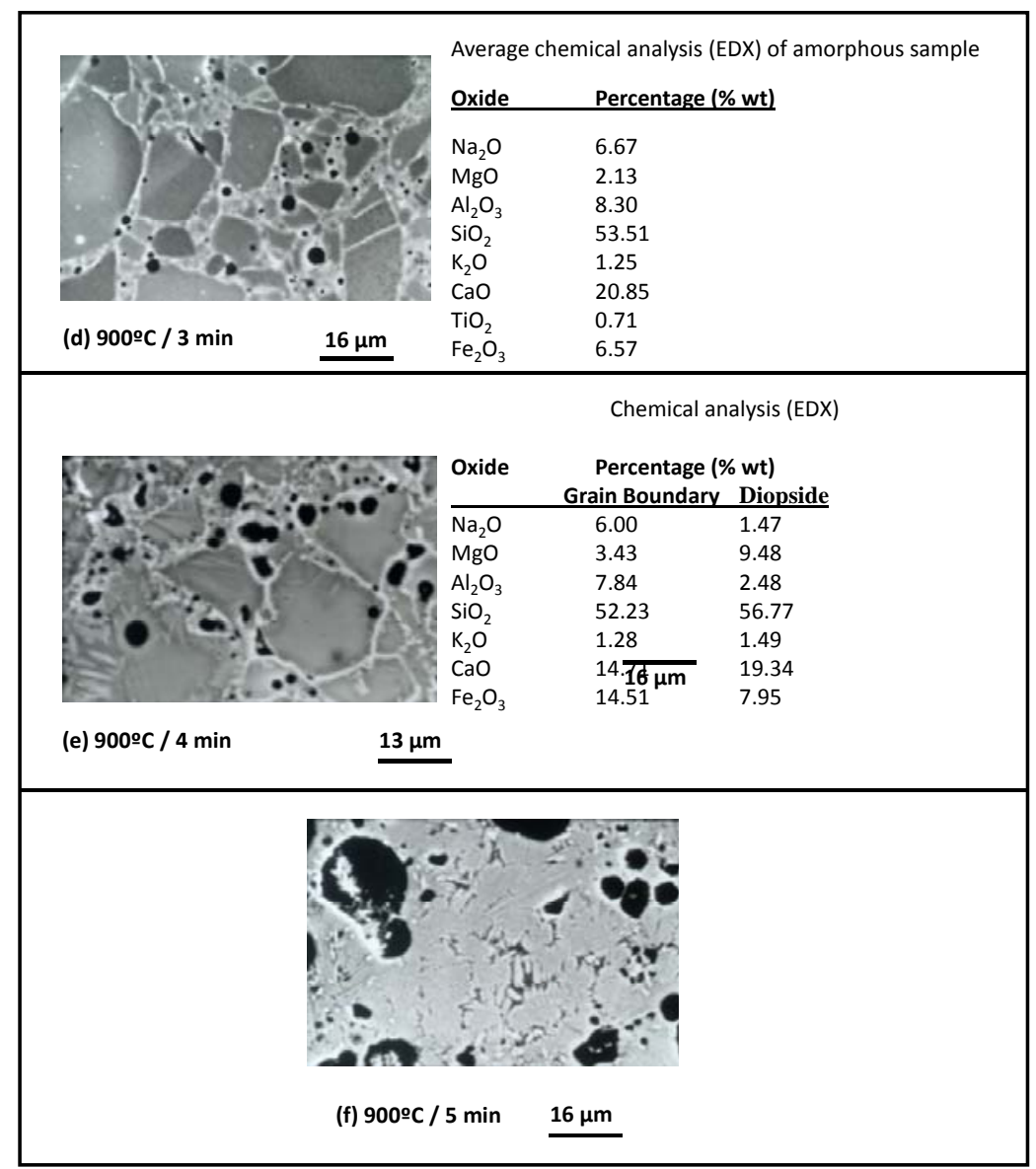

Figure 7. SEM images and EDX analyses of samples heat treated for short times at $900^{\circ} \mathrm{C}$ as indicated by the points labelled (d) and (f) in Figure 2. 
After 30 minutes, a fully crystallised material containing both diopside and wollastonite forms, Figure 8(g1) and (g2). One form of wollastonite crystallises as fibre-like crystals in a dendritic growth morphology (labelled as F in Fig.8(g2). In some areas, between the dendrites blade-shaped crystals (labelled B in Fig.8(g2)) are found. Monoclinic wollastonite usually grows in lathlike aggregates whereas triclinic wollastonite crystallises in tablets or blades [42]. Thus, the two wollastonite morphologies observed by SEM at F and B, probably correspond to monoclinic and triclinic wollastonite, respectively. The wollastonite crystals also has a considerable amount of Fe replacing $\mathrm{Ca}$. Longer heat-treatments at $900^{\circ} \mathrm{C}$ have a negligible effect on the morphology of the crystalline phases. A complementary transmission electron microscopy study of crystallisation in this glass system is underway.

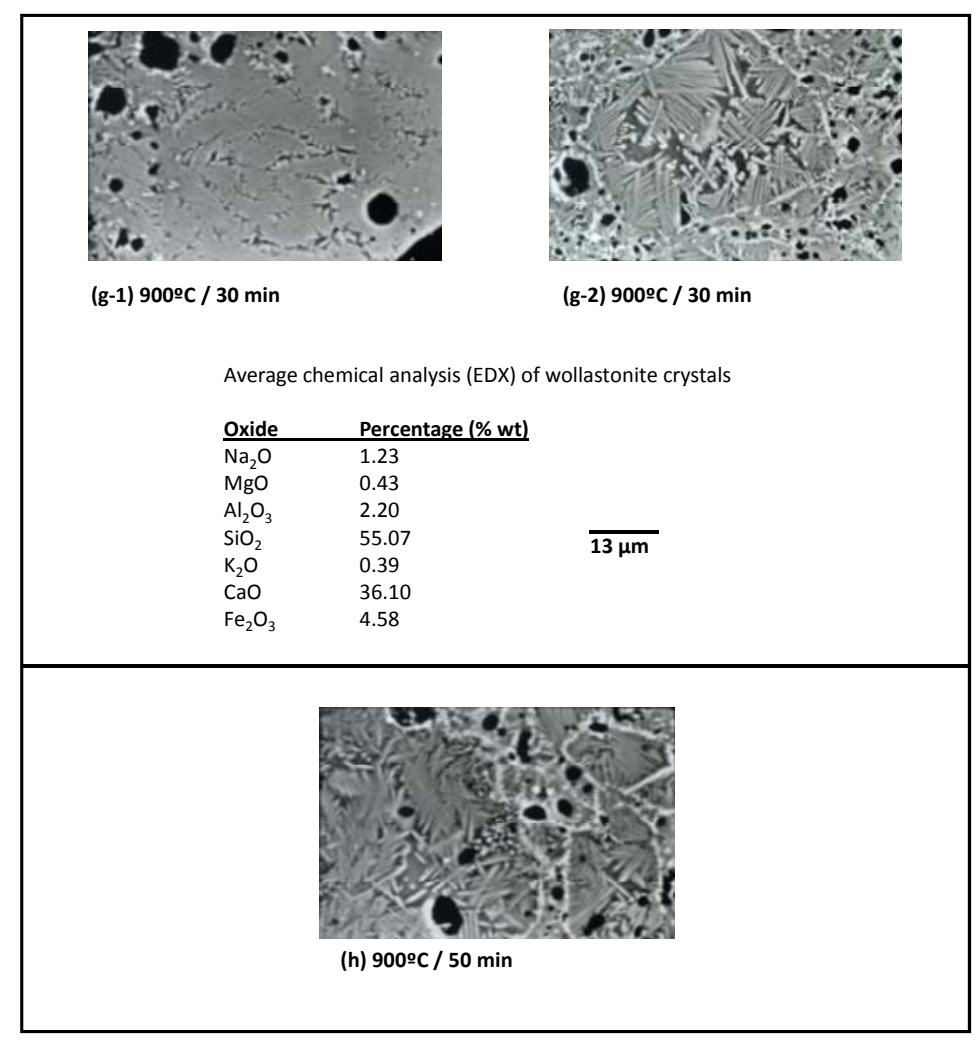

Figure 8. SEM images and EDX analyses of samples heat treated for long times at $900^{\circ} \mathrm{C}$ as indicated by the points labelled (g) and (h) in Figure 2.

\section{CONCLUSIONS}

The possibility of fabricating sintered glass-ceramics from vitrified urban incineration waste that was not capable of bulk crystallisation has been demonstrated. DTA results suggested that crystallisation starts at external surfaces. Thus, this incinerator fly-ash glass, in contrast to some previously investigated, must be converted into a glassceramic by the powder processing route.

TTT diagrams showed that crystal growth started at $775^{\circ} \mathrm{C}$ and was most rapid at $900^{\circ} \mathrm{C}$. The crystalline phases were diopside, monoclinic and triclinic wollastonite. Only diopside is present at $775^{\circ} \mathrm{C}$ but both monoclinic and triclinic wollastonite appear at 
$825^{\circ} \mathrm{C}$. The relative proportion of the three devitrified phases increased with temperature and time, up to $900^{\circ} \mathrm{C}$ and about $50 \mathrm{~min}$, respectively. Times above $20 \mathrm{~min}$ had negligible effect on the amount of triclinic wollastonite whereas times of 40 and 50 min led to the maximum proportions of monoclinic wollastonite and diopside, respectively. Thus the optimum heat treatment time is $40-50$ minutes.

The fully crystallised products showed a morphology corresponding to a final stage of sintering with closed and spherical pores located in both particle boundaries (intergranular) and within the particles (intragranular). The heat treatment caused segregation of $\mathrm{Fe}$ from the interior to the vicinity of the particle boundaries and this eventually led to the formation of an iron-rich phase. Diopside initially grows normal to the boundaries as needle-like crystals, but later develops an interconnected network of crystals. Wollastonite exists in two morphologies, a fibrous dendritic morphology and blade-like crystals, which probably correspond to monoclinic and triclinic wollastonite, respectively. EDX spot analyses showed substitution of $\mathrm{Mg}$ by $\mathrm{Fe}$ in diopside (pyroxene) and Ca by Fe in wollastonite.

Overall, this work has confirmed that a powder processing route constitutes a convenient processing alternative to bulk crystallisation for the fabrication of glassceramics from silicate wastes.

\section{ACKNOWLEDGMENT}

Part of this work was carried out with financial assistance of DAAD (Germany) and Ministry of Education and Culture (Spain) under the program "Acciones Integradas". The experimental assistance of Mrs. P. Díaz (IETcc, Spain) and Mr. C. Rivera (UC-LM, Spain is gratefully appreciated.

\section{REFERENCES}

1. S.S. Amritphale, M. Patel., Utilization of red mud and fly ash for manufacturing bricks with pyrophyllite, Silicates Industriels 3-4 (1987) 31-34.

2. E.A. Domínguez, R. Uhlmann, Ecological bricks” made with clays and steel dust pollutants, Appl.Clay Sci., 11 (1996) 237-249

3. R.S. Thakur, B.R. Sant. Utilization of red mud: Part I- Analysis and utilization as raw material for absorbents, building materials, catalysts, fillers, paints and pigments J.Sci.Ind.Res. 42 (1983) 87-108.

4. C. Allaire. «Use of red mud for the production of aluminium reduction cell potlining refractoires» Am.Ceram.Soc.Bull. 72 (1993) 59-64.

5. M.C. Alonso, M.P. Luxán. Aplicaciones de las Cenizas Volantes en el Campo de la Construcción. Experiencia Española. Ed. ASINEL, PIE, IETcc, Madrid, 1995.

6. M. Romero, J.Ma. Rincón. Surface and bulk crystallisation of glass-ceramic in the $\mathrm{Na}_{2} \mathrm{O}-\mathrm{CaO}-\mathrm{ZnO}-\mathrm{Fe}_{2} \mathrm{O}_{3}-\mathrm{Al}_{2} \mathrm{O}_{3}-\mathrm{SiO}_{2}$ system derived from a goethite waste, J.Am.Ceram.Soc. 82 (1999) 5, 1313-17.

7. L. Barbieri, I. Lancelloti, T. Manfredini, I. Queralt, J.Ma. Rincón, M. Romero. Glasses and glass-ceramics from coal fly ashes, Fuel 78 (1999) 271-276.

8. M. Romero, J.Ma. Rincón, Preparation and properties of high iron oxide content glasses obtained from industrial wastes, J.Eur.Ceram.Soc. 18 (1997) 2, 153-160. 
9. Z. Gao, C.H. Drummond III, Thermal analysis of nucleation and growth of crystalline phases in vitrified industrial waste, J.Am.Ceram.Soc., 82 (1999) 3, 561565.

10. G. Partridge, An overview of glass-ceramics. Part 1. Development and principal bulk applications, Glass Technol., 35 (1994) 116-127).

11. J.Ma. Rincón, M. Romero, Glass-ceramics as building materials, Materiales de Construcción, 46 (1996) 91-106

12. G. Partridge, Glass-ceramics - wide ranging engineering materials. Glass Production Technology International. 1991. Edited by H. Rawson. Sterling Publications International Ltd., London, 203-210.

13. N.E. Priestly. Glass ceramics substrates in advanced microwave integrated circuits. Glass Technol., 31 (1990) 7-10.

14. Y. Takahashi, Y. Benino, V. Dimitrov, T. Komatsu, Transparent surface crystallised glasses with optical non-linear $\mathrm{LaBGeO}_{5}$ crystals, J.Non-Cryst.Solids, 260 (1999) 155-159.

15. J.M. Jewell, E.J. Friebele, I.D. Aggarwal, Transparent heavy metal fluoride glassceramic, J.Non-Cryst.Solids, 188 (1995) 285-288

16. K. Shioya, T. Komatsu, H.G. Kim, R. Sato, K. Matusita, Optical properties of transparent glass-ceramics in $\mathrm{K}_{2} \mathrm{O}-\mathrm{Nb}_{2} \mathrm{O}_{5}-\mathrm{TeO}_{2}$ glasses, J.Non-Cryst.Solids, 189 (1995) 16-24.

17. C. Moisescu, C. Jana, S. Habelitz, G. Carl, C. Rüssel, Oriented fluoroapatite glassceramics, J.Non-Cryst.Solids, 248 (1999) 176-182.

18. C. Moisescu, C. Jana, C. Rüssel, Crystallisation of rod-shaped fluoroapatite from glass melts in the system $\mathrm{SiO}_{2}-\mathrm{Al}_{2} \mathrm{O}_{3}-\mathrm{CaO}-\mathrm{P}_{2} \mathrm{O}_{5}-\mathrm{NaO}-\mathrm{K}_{2} \mathrm{O}-\mathrm{F}^{-}$, J.Non-Cryst.Solids, 248 (1999) 169-175.

19. H. Hosono, Y. Abe, Porous glass-ceramics composed of a titanium phosphate crystal skeleton: A review, J.Non-Cryst.Solids, 190 (1995) 185-197.

20. A. R. Boccaccini, Glass Matrix Composite Materials with Dispersion Reinforcement. A Review, Verre, 5 (1999) 3-14.

21. R. D. Rawlings, Glass-Ceramic Matrix Composites, Composites 25 (1994) 372-379.

22. Z. Strnad, Glass-Ceramics Materials: Liquid phase separation, nucleation and crystallization in glasses. Glass Science and Technology, Elsevier, Amsterdam 1986.

23. W. Pannhorst, Glass-ceramics: State-of-the-art, J.Non-Cryst.Solids, 219 (1997) 198204.

24. Rabinovich, E. M., Cordierite Glass-Ceramics Produced by Sintering, in: Advances in Ceramics Vol. 4, Ed. by J. H. Simmons, D. R. Uhlmann, G. H. Beall, The American Ceramic Society, Columbus (1982) pp. 327-333.

25. K. Nakashima, K. Noda, K. Mori, Time-Temperature-Transformation diagrams for borosilicate glasses and preparation of chemically durable porous glasses, J.Am.Ceram.Soc., 80 (1997) 1101-1110.

26. C. Cantalini, M. Pelino, Characterization of crystal phases, morphology and crystallization processes in lithium aluminosilicate glass-ceramic, J.Mater.Sci, 27 (1992) 448-452.

27. D.R. Uhlmann, A kinetic treatment of glass formation, J.Non-Cryst.Solids, 7 (1974) 337-48.

28. M.C. Weinberg, "Nose method" of calculating critical cooling rates for glass formation, J.Am.Ceram.Soc., 72 (1989) 2054-58.

29. A.R. Boccaccini, M. Köpf, W. Stumpfe. Glass-ceramics from filter dust from waste incinerators. Ceram. Int. 21 (1995) 231-235. 
30. M. Romero, R.D. Rawlings, J.Ma. Rincón. Development of a new glass-ceramic by means of controlled vitrification and crystallisation of inorganic wastes from urban incineration. J.Eur.Ceram.Soc. 5 (1999) 2049-2058.

31. J.Ma. Rincón, M. Romero, A.R. Boccaccini, Microstructural characterisation of a glass and a glass-ceramic obtained from municipal incinerator fly ash, J.Mat.Sci., 34 (1999) 4413-4423.

32. M. Romero, R. D. Rawlings, J.Ma. Rincón, Crystal nucleation and growth in glasses from inorganic wastes from urban incineration, J.Non-Cryst.Solids, in press.

33. A.R. Boccaccini, M. Romero, J.Ma. Rincón, Sintered glass-ceramics from municipal incinerator fly ash, Glass Technology, in press.

34. I. Szabó, Crystallization of magnesium aluminosilicate glasses, J.Non-Cryst.Solids, 219 (1997) 128-135.

35. T. Wakasugi, L.L. Burgner, M.C. Weinberg, A DTA study of crystal nucleation in $\mathrm{Na}_{2} \mathrm{O}-\mathrm{SiO}_{2}$ glasses, J.Non-Cryst.Solids, 244 (1999) 63-73.

36. J.Ma.Rincón, Principles of nucleation and controlled crystallization of glasses, Polym.-Plast.Technol.Eng., 31 (1992) 309-357.

37. A. R. Boccaccini, G. Ondracek, Viscous Sintering of Non-spherical Borosilicate Glass Powder, Glastech. Ber. 65 (1992) 73-78.

38. W.D. Kingery, H.K. Bowen, D.R. Uhlmann, Introduction to Ceramics, Ed. John Wiley \& Sons, New York, 1976.

39. J.Ma. Rincón, P. Callejas, Microanalysis of the surface in glass-ceramics obtained from muscovite-amblygonite, J.Mat.Sci., 23 (1988) 1042-1049.

40. I. Gutzow, R. Pascova, A. Karamanov, J. Schmelzer, The kinetics of surface induced sinter crystallization and the formation of glass-ceramics materials, J.Mat.Sci., 33 (1998) 5265-5273.

41. W.A. Deer, R.A. Howie, J. Zussman, Rock Forming Minerals, Vol.2, Longman, London, 1963.

42. A. Szymanski, Technical Mineralogy and Petrography. An Introduction to Materials technology. Part B, Ed. Elsevier, Amsterdam, 1989. 